\title{
STUDI KASUS MANAJEMEN BEBAN KELUARGA DALAM MERAWAT ANGGOTA KELUARGA GANGGUAN
} JIWA REPASUNG

Family Burden Management In Caring Family Member With Mental Disorder Repasung: A Case Study

\author{
Rasmawati ${ }^{1}$, Rahma Yulis ${ }^{2}$, Hardianti² \\ ${ }^{1 * J u r u s a n ~ K e p e r a w a t a n ~ F a k u l t a s ~ K e d o k t e r a n ~ d a n ~ I I m u ~ K e s e h a t a n ~ U I N ~ A l a u d d i n ~ M a k a s s a r ~}$ \\ 2Jurusan Keperawatan Sekolah Tinggi Ilmu Kesehatan Makassar \\ *) Corresponding Atuhor: rasmawati.ners@uin-alauddin.ac.id \\ No HP: 085255992109
}

\begin{abstract}
Caring people with mental disorder repasung requires care by the family for a long time. This affects the burden and saturation of the family, so it is necessary to carry out the burden of caring for family members who are experiencing repasung. The purpose of this study is to explore the family burdens management in caring for family members with mental disorders who experience repasung. A qualitative design with a multiple instrumental case study approach using two cases chosen to provide an understanding of family burden management. Six families of case subjects participated in this study. The Data collected by in-depth interviews. Three categories were produced, namely Confinement as a choice of repasung forms; Family Perceptions of Repasung Actions; and burden management in caring for family members with mental disorder repasung. Caregiver experiences burnout which results in the desire to release family members and care in the hospital.
\end{abstract}

Keywords : family burden, Mental disorder, repasung,

\section{ABSTRAK}

Perawatan orang dengan gangguan jiwa repasung membutuhkan perawatan oleh keluarga dalam jangka waktu yang lama. Perawatan ini berpengaruh pada beban dan kejenuhan keluarga sehingga perlu mamajenem beban dalam merawat anggota keluarga yang mengalami repasung. Tujuan penelitian ini untuk mengeksplorasi lebih mendalam mengenai manajemen beban keluarga dalam merawat anggota keluarga gangguan jiwa yang mengalami repasung. Desain penelitian menggunakan kualitatif dengan pendekatan descriptive multiple instrumental case study. Dua kasus orang gangguan jiwa repasung dipilih untuk memberikan pemahaman mengenai manajemen beban keluarga dalam merawat. Partisipan penelitian berjumlah 6 orang keluarga subjek kasus. Data dikumpulkan dengan wawancara mendalam. Tiga kategori yang dihasilkan: Kurungan sebagai pilihan bentuk repasung; Persepsi Keluarga Terhadap Tindakan repasung; dan Manajemen beban dalam merawat anggota keluarga dengan gangguan jiwa repasung. Caregiver mengalami kejenuhan yang mengakibatkan keinginan untuk melepaskan anggota keluarga dan merawat di rumah sakit.

Kata kunci : beban keluarga, gangguan jiwa, repasung

\section{PENDAHULUAN}

Kasus pasung masih menjadi masalah di Indonesia meski telah diberlakukan program pemerintah Indonesia Bebas Pasung 2014 dan dilanjutkan hingga tahun 2019 karena belum sepenuhnya tuntas. Rerata Kasus gangguan jiwa berat di Indonesia mencapai 1,7/1000 penduduk dan $14,3 \%$ diantaranya pernah di pasung. Angka pemasungan terbanyak berada di wilayah pedesaan dan umumnya berasal dari ekonomi rendah (Kementerian Kesehatan Republik Indonesia, 2013).

Pemasungan dilakukan oleh keluarga atau masyarakat dengan maksud membatasi gerak orang dengan gangguan jiwa (ODGJ) agar tidak membahayakan diri sendiri dan orang lain disekitarnya (Kemenkes, 2017; Laila, Mahkota, Krianto, \& Shivalli (2018). Metode pemasungan yang

dipilih beragam. Hasil temuan Yusuf, Tristiana, \& Purwo, (2019) beberapa metode pemasungan yang dipilih yaitu: dikurung di dalam kandang yang mirip kandang ternak, dikurung dalam kamar yang dilengkapi pintu besi dan jendela yang dibuat kecil serta diikat menggunakan rantai. Metode pemasungan seperti ini dapat mengakibatkan hilangnya kebebasan ODGJ, hilangnya hak atas pelayanan kesehatan untuk membantu pemulihan (Kemenkes 2017).

Pengekangan ODGJ dengan cara dipasung tidak hanya dilakukan sekali tapi bisa menjadi berulang. Beberapa pasien yang telah lepas pasung dan mendapat perawatan di rumah sakit mengalami repasung. Repasung adalah sebuah tindakan pemasungan kembali pada ODGJ yang sebelumnya 
telah dibebaskan. BBC News, (2016) melaporkan pada tahun 2014, 1.274 kasus pasung dilaporkan di 21 provinsi dan $93 \%$ dikabarkan telah bebas dari praktik pemasungan. Namun, tidak terdaat data mengenai jumlah kasus yang berhasil direhabilitasi dan yang mengalami repasung ketika kembali dirawat oleh keluarga masing-masing. Laporan Tribun Jogja, (2017) melaporkan bahwa kasus di Rumah Sakit Umum Daerah (RSUD) Wonosari sebagian besar kasus pemasungan yang ada di Gunung Kidul adalah kasus repasung. ODGJ yang telah diberikan perawatan dan dibebaskan, pada akhirnya kembali dipasung oleh keluarga. Hal ini disebabkan karena bantuan yang diberikan tidak berkelanjutan, jarak dari pusat kesehatan yang jauh, serta kurangnya pengetahuan masyarakat tentang kesehatan jiwa.

Jarak yang jauh dari pusat layanan kesehatan menyebabkan ODGJ rentan mengalami putus obat. Hasil penelitian oleh Belete, (2017) dari 400 pasien bipolar yang diteliti $140(35 \%)$ memiliki kepatuhan yang rendah terhadap pengobatan mereka. Tidak teraturnya pengobatan dan perawatan yang tidak baik ketika menjalani rawat jalan menyebabkan timbulnya kekambuhan. Kekambuhan ini ditandai dengan munculnya gejala-gejala seperti saat belum mendapatkan perawatan di rumah sakit jiwa. Kondisi ini disebut kekambuhan kembali atau relaps.

Munculnya gejala kekambuhan membuat keluarga berupaya kembali mencari pengobatan ke dokter atau altenatif, namun tingkat kejenuhan dengan kondisi ODGJ yang tidak kunjung membaik membuat keluarga memilih repasung (Wijayanti \& Masykur, 2016). Hasil penelitian yang sama oleh (Reknoningsih, Daulima \& Putri, 2015) bahwa pasien pascapasung yang kembali dirawat oleh keluarga menunjukkan penurunan kondisi berupa munculnya perilaku agresif yang kemudian menjadi alasan dilakukannya repasung oleh keluarga. Repasung menurut Katuuk et al. (2019) dilakukan oleh keluarga bertujuan menciptakan lingkungan yang aman bagi pasien dengan masalah kesehatan mental.

Penyebab lain repasung menurut hasil penelitian Astuti, (2017) menemukan bahwa setelah pengobatan di pelayanan kesehatan ada ODGJ yang mengalami repasung. Hal ini disebabkan karena keluarga tidak mampu merawatnya sesuai dengan kaidah-kaidah rehabilitasi sosial serta ekonomi keluarga yang umumnya tergolong rendah, membuat mereka tidak bisa bisa fokus mendampingi anggota keluarganya yang ODGJ.

Repasung sebagai pilihan penyelesaian masalah, ternyata tetap menjadi beban bagi keluarga yang merawat. Penelitian Shamsaei, (2015) menemukan bahwa keluarga yang merawat ODGJ memiliki skor beban dari tingkat sedang hingga berat sebesar $41,8 \%$ dan yang mengalami beban berat sebesar $27,1 \%$. Tingkat beban yang dialami oleh keluarga yang merawat keluarga dengan skizoprenia memiliki hubungan yang signifikan dengan usia, jenis kelamin, kedekatan hubungan, lama merawat dan lama penyakit.

Penyebab ODGJ berpotensi mengalami repasung menurut Reknoningsih, Daulima dan Putri, (2015) adalah keluarga yang merawat ODGJ mengalami kesulitan melakukan menajemen beban yang kemudian menimbulkan dampak berupa kelelahan fisik dan pergolakan emosi. Penelitian oleh Suharto, (2014) menemukan bahwa ada hubungan yang bermakna antara kedekatan keluarga yang merawat ODGJ dengan aspeknya. Beban keluarga akan dirasakan lebih berat pada individu yang mempunyai hubungan langsung dengan ODGJ hal ini disebabkan karena rasa berduka dan kehilangan keluarga atas hilangannya mimpi, harapan dan citacita ODGJ.

Perawatan untuk pasien dengan skizofrenia di rumah merupakan beban yang cukup besar bagi keluarga. Nasr dan Kausar, (2009) menyatakan penghentian atau kehilangan pekerjaan pasien, serta kesulitan yang dihadapi oleh anggota keluarga yang peduli yang mungkin merasa sulit untuk melanjutkan pekerjaan karena tanggung jawab ekstra mereka, akan berkontribusi pada beban keuangan. Selain itu, pengeluaran yang dikeluarkan untuk perawatan, obat-obatan, dan kadang-kadang transportasi karena rawat inap jauh dari rumah juga menambah alasan beban keuangan pada keluarga.

Pilihan repasung diplih dengan tujuan untuk mengurangi beban keluarga akan tetapi merawat ODGJ dengan repasung tetap membuat beban sendiri karena ODGJ tetap butuh perhatian Mengatasi masalah ini dibutuhkan manajemen beban dari keluarga yang merawat anggota keluarga yang mengalami repasung. Tujuan penelitian ini untuk mengeksplorasi lebih mendalam melalui studi kasus mengenai manajemen beban keluarga dalam merawat anggota keluarga gangguan jiwa yang mengalami repasung.

\section{METODE}

Metode penelitian pada penelitian adalah kualitatif dengan pendekatan descriptive multiple instrumental case study yaitu meneliti beberapa kasus kemudian dibuat dalam bentuk ilustrasi untuk memberikan pemahaman tentang suatu masalah. Penelitian ini meneliti dua kasus ODGJ agar mendapatkan pemahaman yang mendalam mengenai manajemen beban keluarga merawat anggota keluarga gangguan jiwa re pasung. Lokasi penelitian bertempat di Kabupaten Luwu, sebuah kabupaten di Provinsi Sulawesi Selatan yang berjarak $500 \mathrm{Km}$ dari fasilitas Rumah Sakit Jiwa yang ada di Kota Makassar. Waktu penelitian Mei- Juli 
2019.

Partisipan pada peneltian ini adalah keluarga dan orang- orang terdekat ODGJ yang berperan penting dalam pemasungan kembali ODGJ. Partisipan dipilih menggunakan metode purposive sampling yaitu partisipan dipilih sesuai dengan tujuan penelitian dan kriteria inklusi yaitu: keluarga yang merawat/ anggota keluarga dan tokoh masyarakat. Subjek kasus yaitu ODGJ yang mempunyai riwayat pemasungan kembali setelah menjalani pengobatan di rumah sakit. Metode pengumpulan data dimulai dengan membuat panduan wawancara sesuai tujuan penelitian, lembar observasi dan catatan lapangan. Tahap selanjutnya melakukan wawancara semi terstruktur dan hasil wawancara direkam memakai sebuah alat perekam suara. Hasil rekaman kemudian dibuat dalam bentuk verbatim untuk kemudian dilakukan analisa data. Analisa data dilakukan dengan menggunakan metode Miles dan Huberman (1994) dalam Yin, (2009) yaitu informasi yang telah diperoleh disusun dalam sebuah tabel, kemudian membuat matriks kategori dan disajikan dalam bentuk flowchart.

Peneliti melakukan pertimbangan etik saat melakukan penelitian dengan menerapkan prinsipprinsip etik. Keseluruhan proses penelitian mengacu pada prinsip etika penelitian dari Polit dan Beck, (2012) yaitu memenuhi prinsip Anonymity dan confidentiality, beneficience, dan justice. Prinsip anonymity dan confidentiality artinya peneliti menjamin kerahasian data partispan dengan tidak mencantumkan nama pastisan pada kuesioner dan laporan hasil penelitian. Prinsip beneficence yaitu manfaat dari penelitian lebih besar dari risiko atau kerugian yang ditimbulkan, menghormati harkat dan martabat manusia. Prinsip keadilan (justice) yaitu partisipan berhak mendapatkan perlakuan yang adil dan tetap menjaga kebebasan diri. Hal penting lainnya selain masalah etik adalah keabsahan data. Kualitas data dari suatu penelitian kualitatif ditentukan oleh keabsahan data yang dihasilkan.

Keabsahan dan validitas data ditentukan dengan menggunakan empat langkah yaitu kredibilitas, dependabilitas, konfirmabilitas, dan transferabilitas (Creswell, 2013). Kredibilitas dilakukan dengan terlibat langsung dalam pengumpulan data, mengamati kondisi partisipan dan melakukan validasi kembali data dengan dengan mendatangi partisipan secara individual untuk menyepakati, menambahkan atau mengurangi data. Pada saat melakukan member check, semua partisipan menyetujui kesimpulan hasil wawancara dengan menandatangani lembar surat pernyataan telah dilakukan member check supaya lebih otentik. Langkah selanjutnya Dependibilitas merupakan kriteria yang menunjukkan bahwa hasil temuan bisa diulangi pada saat yang berbeda dengan partisipan, metode, dan kondisi yang sama. Dependibilitas dilakukan dengan menelaah data dan dokumen dengan benar dan kemudian diserahkan kepada eksternal reviewer untuk diaudit.

Tahap konfirmabilitas dilakukan dengan mengkonfirmasi hasil wawancara, observasi dan catatan lapangan kepada partisipan untuk mendapatkan persetujuan partisipan apakah sesuai dengan hasil wawancara sehingga obejktivitas dapat dijamin. Tahap terakhir adalah transfreabilitas yaitu membuat penjelasan lengkap mengenai hasil penelitian (thick description) yang memungkinkan orang lain memahami bagaimana menerapkan hasil penelitian ini pada setting yang lain. Peneliti membuat penjelasan yang lengkap, jelas, detail, dan sistematis sehingga dapat dimengerti oleh pembaca dan mampu menggambarkan pengalaman keluarga dengan ODGJ yang menjalani repasung.

\section{HASIL}

Sejumlah Enam pastisipan berpartisipasi dalam penelitian ini. Partisian merupakan keluarga dari subjek kasus. MS, SN, dan HR yang merupakan keluarga dari subjek kasus 1 dan MR, MI, dan BI merupakan keluarga subjek kasus 2

Kasus pertama merupakan ODGJ yang mengalami tindakan repasung selama 14 tahun dan telah mengalami gangguan jiwa selama 20 tahun. Model pasung yang digunakan berupa kurungan dalam ruangan $3 \times 3$ meter yang berlokasi dibelakang rumah salah satu saudaranya. Tindakan repasung yang dilakukan oleh keluarga merupakan alternative pilihan terakhir setelah sebelumnya keluarga membawa anggota keluarga ke pengobatan alternative, memasung anggota keluarga menggunakan balok kayu, namun karena adanya atrofi ekstremitas yang dialami oleh subjek kasus, keluarga melepaskan anggota keluarga dengan gangguan jiwa dan membawa berobat ke rumah sakit. Ketidakefektifan pengobatan pasca perawatan rumah sakit menyebabkan subjek kasus kambuh dan membuat keluarga kembali melakukan pemasungan

Kasus kedua merupakan ODGJ yang mengalami gangguan jiwa sekitar 12 tahun dan telah dilakukan tindakan repasung selama 10 tahun. Pemasungan kembali dilakukan setelah keluarga merasa jenuh dengan pilihan pengobatan sebelumnya. Bentuk perawatan yang telah dilakukan oleh keluarga adalah memasung anggota keluarga dengan ganguan jiwa menggunakan balok dan rantai, membawa ke pengobatan alternative, membawa ke rumah sakit jiwa dan melakukan pemasungan kembali sebagai pilihan terakhir yang dapat dilakukan oleh keluarga.

Empat kategori yang dihasilkan dalam penelitian ini yaitu 1) kurungan sebagai pilihan bentuk repasung; 2) Persepsi keluarga terhadap tindakan re pasung; 3) Manajemen beban dalam merawat anggota keluarga dengan gangguan jiwa re 
Vol. 10 No. 022019

e-issn : 2622-0148, p-issn : 2087-0035

pasung yang terdiri dari sub kategori pemilihan lokasi pasung dan pembagian tugas perawatan

\section{Kategori 1. Kurungan sebagai pilihan bentuk repasung}

Keluarga menganggap pembatasan gerak dengan melakukan pasung menggunakan balok kayu merupakan tindakan yang dapat mencederai subjek kasus sehingga pada tindakan pemasungan kembali anggota keluarga dengan gangguan jiwa, keluarga lebih memilih metode kurungan sebagai bentuk pengekangan yang dianggap lebih baik daripada menggunakan balok kayu. Hal ini disampaikan oleh pernyataan partisipan sebagai berikut:

"Ini kan nda dipasung namanya cuma dikurung. lebih bagus ini sih, dikurung. kita nda sampai hati kalau dipasung. nda tega, sampai kita lepas" (HR)

"Cuma dikurung, kubikinkan kamar, tempat buang air". (BI)

"Ini jalan terbaik dikurung, karena nda bisa diobati. Sesudah membunuh. Saya dak pasung, saya kasian liat kalau dipasung" (BI)

\section{Kategori 2: Persepsi Keluarga Terhadap Tindakan repasung \\ Keluarga menganggap mengurung} merupakan upaya terbaik yang bisa dilakukan. Selain sebagai bentuk pengekangan, pemasungan kembali anggota keluarga dianggap sebagai langkah terbaik untuk menghindarkan anggota keluarga dari stigma masyarakat. Hal ini diungkapkan oleh partisipan:

"saya lebih baik dikurung, kalau sekarang tetangga tidak ada cerita, nda ada, aman." (MS)

"Aman dia di rumah baru, tapi tidak dirantaui, kita yang punya perasaan kalau dilepas mungkin dia lebih enak kelihatannya tapi telanjangnya ini" (SN)

"Itu kalau nda dikurung orang-orang malah terganggu, karena mereka merasa ketakutan. Jadi mending kayak sekarang (dikurung) (MR)

Selain dapat menghindarkan anggota keluarga dari stigma masyarakat, pasung dengan menggunakan metode kurungan dianggap keluarga sebagai cara perawatan yang dapat menurukan beban keluarga dalam merawat. Hal ini diungkapkan oleh partisipan:

"saya juga nyaman, pulang dari pasar, kasi nasi terus istirahat." (MS)

"Saya Ikhlas kasi makan, saudara, apalagi mamaku berpesan. Nda ada yang bisa kasi makan kecuali saya. Biar saudara perempuan lainnya."(MS)

Sebagai caregiver yang memiliki tugas lebih banyak dari caregiver lainnya, dua partisipan mengaku lebih memilih subjek kasus dirawat di rumah sakit untuk meringankan beban yang dialami, namun tidak terlaksana karena tidak terjadi kesepakatan antar semua anggota keluarga. Hal ini diungkapkan oleh partisipan sebagai berikut
"Kalau saya itu saya senang kalau dibawa ke rumah sakit, karena sudah kurang saya punya kerjaan, Tapi itu kan perlu persetujuan juga, tidak bisa cuma saya bilang ayok ke rumah sakit kalau nda didukung juga, nda bisa juga." (HR)

"Kemarin ada rencananya mereka-mereka itu (keluarga) bawa ke rumah sakit, tapi nda tau, saya kan ipar to, kataya mau dibawa, ada yang bilang bawa, ada yang bilang tidak." (MR)

Tidak terdapatnya kesepakatan antar anggota keluarga untuk kembali membawa anggota keluarga berobat ke rumah sakit menyebabkan keluarga melakukan manajemen beban dalam merawat anggtoa keluarga yang mengalami repasung

\section{Kategori 3: Manajemen beban dalam merawat anggota keluarga dengan gangguan jiwa re pasung}

Keluarga kedua subjek kasus memiliki pembagian peran dalam manajemen perawatan terhadap anggota keluarga yang mengalami repasung sebagai bentuk komitment perawatan keluarga karena tidak mengalami kesepakatan untuk membawa kebobat ke rumah sakit. Hal yan dilakukan adalah membuat jarak lokasi pasung yang tidak berjahuan dengan dengan caregiver serta melakukan pembagian peran dan tugas dalam merawat anggota keluarga

\section{Pemilihan lokasi pasung}

Posisi/lokasi tempat pemasungan mempengaruhi kemampuan keluarga dalam memberikan perawatan terhadap anggota keluarga yang mengalami repasung. Lokasi yang jauh dari caregiver menimbulkan beban yang berpengaruh terhadap motivasi keluarga dalam merawat. Pemilihan lokasi pemasungan yang dekat dari caregiver menyebabkan caregiver mampu melakukan perawatan yan lebih baik. Hal ini diungkapkan oleh partisipan sebagai berikut:

"Saya pindahkan kesini, kalau dulu disana (di rumah saudara yang lain) kan dia jauh, jadi kadang 2 bulan sekali saya bersihkan, kalau disini kan dekat kita disini (jarak sekitar 30 meter), jadi kadang saya bersihkan sebulan sekali, Alhamdulillah artinya kan saya itu merawatnya dekat sekarang, nda sama dulu. (HR)

"Rencana saya mau pindahkan kesini di belakang rumah. Tapi nda tau nanti ini, karena mau diongkosi juga bikin rumah batu. Karena kalao disana setengah mati juga anakku antarkan makanan kesana, mulai mengeluh anak ku juga kerena jauh" (BI)

\section{Pembagian tugas perawatan}

Perawatan anggota keluarga yang mengalami re pasung merupakan perawatan yang membutuhkan jangka waktu yang lama sehingga keluarga melakukan pembagian tugas dalam 
merawat anggota keluarga gangguan jiwa. Pembagian tugas yang dibuat oleh keluarga meliputi pembagian materi dan non materi. Hal ini tergambar dari pernyataan partisipan keluarga subjek kasus berikut:

Subjek kasus 1:

Kami bagi tugas kemarin bikinkan pondok dirembuk saya batakonya, saya semennya, saya besinya. anaknya JR (anak saudaranya) tukang sekop, angkat batako pake tenaga begitu, nda pake dana, dananya dari kami yang nda ikut pake tenaga gitu kan. (HR)

"Pak HR yang setengah mati yang siramkan kotorannya, dia yang siram saya yang kasi makan" (MS)

Berasnya itu dari SN (saudara laki-laki) yang punya gilingan, dia kasi beras. Lauk pauknya ya usaha sendiri MS, saling bantu. (HR)

Kalau obat nyamuknya inisiatif saya sendiri yang lakukan. saya sendiri juga yang tanggung obat nyamuknya to, tadinya waktu disana itu pake air munum air sumur tapi setelah dsini tidak boleh pake begitu (air sumur mentah), ada gallon dibelikan.(HR) "Kalau bagian tainya saya, kasi minum, kasi obat nyamuk saya, sampai sekarang" (HR)

"Satu tahun satu kali mandi lebaran pi kumpul keluarga baru bisa semua keluarga masuk ada yang pegang, baru di cukur, mandi bersih baru dibersihkan tempatnya lebaran di situ" (MS)

\section{Subjek kasus 2:}

"Dulu saya yang kasi makan disini, ada mungkin 5 tahun saya kasi makan, sekarang yang kasi makan MI sama Bl, datang kesini dia kasi makan. kalau saya yang kasi makan nabilangnya racun, jadi dia tidak mau. (MR)

"Kalau Hj. Y (saudara) rokoknya dia yang jamin. Biasa dibelikan kasur kalau rusak lagi kasurnya. $\mathrm{Hj}$. $K$ kalau kasurnya, Kalau saya bawakan nasi, anak ku bawakan setiap hari" (BI)

"Kalau datang sepupunya dari Makassar, dia biasa kasi mandi, cukur, kalau orang disini nda mau. kalau sarungnya nda mau juga kalau diganti, jadi pakaian kotornya terkumpul dibelakang. Jadi setiap dikasi pakaian dia pakai tapi kalau kotor nda mau dibuang. "(MI)

Dari pernyataan partisipan baik keluarga subjek kasus 1 maupun subjek kasus 2, tergambar adanya pembagian tugas dan beban dalam merawat anggota keluarga yang mengalami repasung.

\section{PEMBAHASAN}

Kasus pemasungan kembali (repasung) pada orang gangguan jiwa masih dijumpai pada beberapa daerah. Terjadinya kasus repasung dapat disebabkan karena beberapa hal diantaranya kurangnya pengetahuan keluarga tentang hak-hak ODGJ dan upaya pemulihan dan rehabilitasi social
(Rasmawati, Daulima and Wardani, 2018). Hal lainnya yang adalah kurangnya pemahaman keluarga mengenai peran peran yang harus dilakukan dalam pemulihan keluarga yang mengalami gangguan jiwa setelah lepas pasung. Keterbatasana Ekonomi keluarga, serta stigma dari masyarakat paska pengobatan dan rehabilitasi social setelah ODGJ mengalami pembebasan pasung (Astuti, 2017). Bentuk repasung yang dilakukan oleh keluarga dapat sama maupun berbeda dengan bentuk pasung sebelumnya.

Bentuk pemasungan yang lazim digunakan yakni merantai atau mengikat pada kayu/pohon. Bentuk lain dapat berupa kurungan dalam ruangan yang berada didalam maupun diluar rumah. Pemasungan dalam bentuk kurungan dianggap oleh keluarga merupakan bentuk pembatasan gerak yang paling baik karena tidak menimbulkan luka dan membuat ODGJ lebih aman karena terhindar dari pandangan masyarakat sekitar. Hal ini pula diungkapkan oleh penelitian dengan partisipan 9 orang yang mengalami pemasungan, delapan pasien dipasung dengan cara dikurung dan 1 pasien dipasung dengan cara dirantai (Yusuf, Tristiana and Purwo, 2019)

Keluarga menganggap pelaksanaan pemasungan pada anggota keluarga dengan gangguan jiwa, dapat meringankan beban, karena keluarga yang merupakan pekerja dapat melaksanakan tugas dan tanggung jawab mencari nafkah sekaligus tetap mampu memberi makan pada anggota keluarganya yang mengalami gangguan jiwa. Hal ini sejalan dengan penelitian yang mengungkapkan bahwa keluarga tidak mempunyai pilihan untuk bisa merawat pasien sehingga dengan terpaksa harus memasung pasien karena jika tidak dipasung, keluarga hanya akan menghabiskan waktu untuk merawat pasien dan tidak dapat bekerja mengurus lahan pertanian (Yusuf, Tristiana and Purwo, 2019). Pemasungan sebagai alternatif terakhir karena upaya terkait segala jenis pengobatan telah ditempuh oleh keluarga. Pemasungan kembali dilakukan sebagai upaya perlindungan dan bentuk kepedulian keluarga terhadap subjek kasus tidak ada upaya untuk menutupi ODGJ (Wijayanti and Masykur, 2016)

Tindakan repasung yang dilakukan oleh keluarga dapat meningkatkan beban merawat yang dialami oleh garegiver utama. Pastisipan mengungkapkan beban yang dialami lebih berat dari beban saudara-saudara lainnya yang juga ikut merawat karena memiliki tanggung jawab yang lebih besar. Selain memiliki tanggung jawab merawat anggota keluarga gangguan jiwa, partisipan juga bertanggung jawab mencari nafkah untuk keluarga sehingga lebih memilih utuk membawa ke rumah sakit. Penelitian yang dilakukan oleh Siddiqui dan Khalid, (2019) menunjukkan bahwa merawat anggota 
keluarga dengan gangguan jiwa yang serius berdampak pada kesejahteraan caregiver. Semakin lama durasi gangguan jiwa dan semakin meningkatnya kebuthan perawatan, maka semakin banyak beban yang dialami oleh caregiver, terutama caregiver yang menikah, kurang berpendidikan, dan tinggal di daerah pedesaan.

Beban yang tinggi yang dialami oleh caregiver membutuhkan manajemen pembagian beban antar anggota kelaurga. Pembagian beban yang dilakukan oleh keluarga subjek kasus berupa pembagian beban dalam penyediaan tempat tinggal, pemberian makan, kebersihan, dan keamanan subjek kasus. Memaksimalkan penerapan manajemen perawatan pada pasien dapat mengurangi beban keluarga dalam merawat. Intervensi program pelatihan perawatan yang layak dapat meningkatkan kompetensi pengasuhan keluarga termasuk pengetahuan, sikap, dan keterampilan merawat (Purba, Suttharangsee and Chaowalit, 2016). Rahman dan Awaluddin, (2019), menunjukkan adanya perbedaan tingkat pengetahuan dan sikap responden setelah dilakukan penyuluhan pada keluarga pasien halusinasi. Studi lainnya menunjukkan bahwa beban keluarga secara signifikan lebih rendah pada keluarga yang menerima kombinasi dari terapi psikoedukasi keluarga dan terapi perawatan keluarga tanpa pasung dibandingkan dengan hanya psikoedukasi keluarga (Dewi, Daulima \& Wardani, 2019).

Perawatan total dan dalam jangka waktu yang lama pada gangguan jiwa yang mengalami repasung dapat meningkatkan resistensi perawatan oleh keluarga sehingga selain peningkatan kemampuan merawat keluarga diperlukan pula peningkatan kemandirian pasien dengan melakukan tindakan perawatan tanpa pasung.

\section{KESIMPULAN}

Manajemen beban yang dilakukan keluarga meliput pembagian tugas dan peran baik dalam hal dukungan instrumental maupun finansial dalam merawat anggota keluarga gangguan jiwa repasung. Manajemen beban semakin tidak efektif sejalan dengan lama waktu repasung yang dijalani oleh ODGJ sehingga caregiver mengalami kejenuhan yang mengakibatkan keinginan untuk melepaskan kembali anggota keluarga dan merawat di rumah sakit.

\section{SARAN}

Keterlibatan dan dukungan semua anggota keluarga diperlukan dalam perawatan anggota keluarga gangguan jiwa repasung dan dibutuhkan manajemen perawatan tanpa pasung agar hak ODGJ dapat terlindungi. Perlu penelitian lanjutan mengenai terapi kognitif pada keluarga sehingga keluarga mampu mengubah pikiran untuk merawat anggota keluarga tanpa pasung

\section{UCAPAN TERIMA KASIH}

Ucapan terima kasih diampaikan kepada Kementerian Pendidikan dan Kebudayaan DIKTI atas hibah Penelitian Dosen Pemula dengan judul proposal Analisis Dampak Beban Keluarga Terhadap Keputusan Pemasungan Kembali Anggota Keluarga Dengan Gangguan Jiwa.

\section{DAFTAR PUSTAKA}

Astuti, M. (2017) 'kondisi orang dengan gangguan jiwapasung, keluarga dan masyarakat lingkungannya di kabupaten 50 kota', Sosio Konsepsia, 6(03), pp. 256-268.

BBC News (2016) 'Setidaknya 18.800 orang masih dipasung di Indonesia'.

Belete, H. (2017) 'Use of physical restraints among patients with bipolar disorder in Ethiopian Mental Specialized Hospital , outpatient department : cross - sectional study', International Journal of Bipolar Disorders. Springer Berlin Heidelberg, 17(5), pp. 2-6. doi: 10.1186/s40345-017-0084-6.

Creswell, J. H. (2013) Qualitatif Inquiry \& Research Design. 3rd edn. United States of America: Sage Publication.

Dewi, A. rahma, Daulima, N. helena C. and Wardani, I. Y. (2019) 'Managing family burden through combined family psychoeducation and care decision without pasung therapies', Enfermería Clínica, 29(2).

Kementerian Kesehatan Republik Indonesia (2013) RISET KESEHATAN DASAR.

Laila, N. H. et al. (2018) 'Perceptions about pasung ( physical restraint and confinement ) of schizophrenia patients : a qualitative study among family members and other key stakeholders in Bogor Regency, West Java Province, Indonesia 2017', International Journal of Mental Health Systems. BioMed Central, 12(35), pp. 1-7. doi: 10.1186/s13033-018-0216-0. 
Nasr, T. and Kausar, R. (2009) 'Psychoeducation and the family burden in schizophrenia : a randomized controlled trial', Annals of General Psychiatry, 8(17), pp. 1-6. doi: 10.1186/1744-859X-8-17.

Polit, D. F. and Beck, C. T. (2012) Nursing research generating and assessing evidence for nursing practice. 9th edn. Philadelphia: Lippincolt Williams \& Wilkins.

Purba, J. M., Suttharangsee, W. and Chaowalit, A. (2016) 'Effects of a Caregiver Coaching Program on Family Caregivers ' Competencies for Persons With Schizophrenia : a Pilot Study', Journal of Health Research, 30(4), pp. 267-274. doi: 10.14456/jhr.2016.36.

Rahman and Awaluddin, sri wahyuni (2019) 'Pengaruh Penyuluhan untuk meningkatkan pengetahuan dan sikap keluarga tentang stratei pelaksanan halusinasi di puskesmas manggala', Jurnal Media Keperawatan: Politeknik Kesehatan Makassar, 10(01), pp. 31-36.

Rasmawati, Daulima, N. helena C. and Wardani, I. Y. (2018) 'The experience of people with mental disorders in social function adaptation after suffering from pasung', Enfermería Clínica, 28(1), pp. 5-9.

Reknoningsih, W., Daulima, N. helena C. and Putri, Y. susanti eka (2015) 'Pengalaman keluarga dalam merawat pasien pasca pasung', Jurnal Keperawatan Indonesia, 18(3), pp. 171-180.

Shamsaei, F. (2015) 'Burden on Family Caregivers Caring for Patients with Schizophrenia', pp. 239-245.

Siddiqui, S. and Khalid, J. (2019) 'Factors associated with the burden of family caregivers of patients with mental disorders: A cross-sectional study', BMC Psychiatry. BMC Psychiatry, 35(5), pp. 1239-1333. doi: 10.12669/pjms.35.5.720.

Suharto, B. (2014) 'Budaya Pasung dan Dampak Yuridis Sosiologis (Studi Tentang Upaya Pelepasan Pasung dan Pencegahan Tindakan Pemasungan di Kabupaten Wonogiri)', Indonsian Journal on Medical Science, 1(2), pp. 1-10.

Tribun Jogja (2017) 'Korban Pasung yang Telah Dibebaskan, Mayoritas Kembali Dipasung Karena Alasan Ini Tribun Jogja'.

Wijayanti, A. P. and Masykur, A. M. (2016) 'LEPAS UNTUK KEMBALI DIKUNGKUNG: STUDI KASUS PEMASUNGAN KEMBALI EKS PASIEN GANGGUAN JIWA', Empati, 5(4), pp. 786-798.

Yusuf, A., Tristiana, R. D. and Purwo, I. (2019) 'Fenomena Pasung dan Dukungan Keluarga terhadap Pasien Gangguan Jiwa Pasca Pasung Grasped Phenomena and Family Support on Post Grasped Psychiatric Patients', jkp, $5(3)$. 